Revista de la red interuniversitaria de estudios sobre las literaturas rioplatenses contemporáneas en Francia

$7 \mid 2012$

Arqueologías

\title{
El pintor de un ocaso. Enrique Loncán entre brindis y charlas de amigo
}

\section{Adriana Rodríguez Pérsico}

\section{OpenEdition}

\section{Journals}

Edición electrónica

URL: http://journals.openedition.org/lirico/648

DOI: $10.4000 /$ lirico.648

ISSN: 2262-8339

Editor

Réseau interuniversitaire d'étude des littératures contemporaines du Río de la Plata

\section{Referencia electrónica}

Adriana Rodríguez Pérsico, «El pintor de un ocaso. Enrique Loncán entre brindis y charlas de amigo », Cuadernos LIRICO [En línea], 7 | 2012, Puesto en línea el 11 octubre 2012, consultado el 01 mayo 2019. URL : http://journals.openedition.org/lirico/648 ; DOI : 10.4000/lirico.648

Este documento fue generado automáticamente el 1 mayo 2019.

\section{cc) $(1) \odot$}

Cuadernos LIRICO está distribuido bajo una Licencia Creative Commons Atribución-NoComercialSinDerivar 4.0 Internacional. 


\title{
El pintor de un ocaso. Enrique Loncán entre brindis y charlas de amigo
}

\author{
Adriana Rodríguez Pérsico
}

1 En 1916, se produce un hecho relevante para la democracia : el partido radical llega al poder con la figura de Hipólito Yrigoyen en elecciones que dejan atrás la práctica extendida del fraude. El radicalismo permanecerá dieciséis años en el gobierno, hasta su derrocamiento en 1930. Durante las décadas de 1920 y 1930, una serie de escritores y periodistas cultivan la crítica política en textos que fusionan costumbrismo y humor. Con algunas excepciones, prefieren las formas breves, ya sea el cuento, el aguafuerte o la causerie. Arturo Cancela, Enrique Loncán, Enrique Méndez Calzada llegan con sus escritos a un público amplio porque colaboran en periódicos y revistas de gran tirada como La Nación, El Hogar, Caras y Caretas. Profundamente escépticos, son antiyrigoyenistas y a fuerza de tanto negativismo, antidemocráticos. El blanco de sus risas es el gobierno nacional y popular. Muestran una Argentina que, entre la ruina de las instituciones, se vislumbra como una sociedad en pedazos.

2 Pero no sólo atentan contra los tiempos presentes. Los textos ponen en marcha una operación de desmitificación extendida de los grandes relatos nacionales. De otro modo, la risa y el estereotipo corroen la solemnidad y los mitos creados por los escritores del Centenario. En 1930, Cancela escribe :

Por desgracia yo no creo en los mitos ; y digo por desgracia porque mi incredulidad en ellos me impide escribir libros de aliento. La fe en los mitos literarios, históricos y sociológicos es, por cierto, el mayor aliciente de la producción artística. El mito del gaucho ha dado origen a Don Segundo Sombra; el del indianismo a casi toda la obra de Rojas; el del helenismo al Payador, a las Industrias de Atenas y a las traducciones homéricas de Leopoldo Lugones; el del hispanismo al Solar de la raza de Manuel Gálvez, a Las bodas de Don Juan de Carlos Noel y a otras equivalentes. ${ }^{1}$

El escritor hubiera coincidido con Roland Barthes (en Mythologies) cuando afirma que el mito no niega las cosas sino que las purifica, las funda en la naturaleza y por consiguiente, en la eternidad. Los relatos de la nación comparten con los relatos míticos algunas 
estrategias discursivas como ser la supresión de las referencias históricas, la identificación y la tautología.

4 Me centraré en estos dos momentos literarios e históricos fundamentales en la vida argentina del siglo pasado : 1910, año del Centenario de la Revolución de Mayo y 1930, que inaugura la funesta tradición de los golpes militares. En esta elección, dejo de lado las cuestiones, fructíferas por cierto, que las vanguardias articulan en torno al nacionalismo y al cosmopolitismo. Como sabemos, se trata de una época en que los movimientos nacionalistas conocen una efervescencia inusitada en el mundo entero aunque sus comienzos pueden retrotraerse hasta las postrimerías del siglo XIX ; en Argentina alcanza su auge alrededor del Centenario. Una serie de intelectuales y escritores -Leopoldo Lugones, Manuel Gálvez, Ricardo Rojas, para nombrar a los más representativosproducen ensayos que imaginan identidades colectivas para la nación desplegando genealogías reales o inventadas, linajes deseados y memorias verdaderas o falsas. Los escritores nacionalistas se dan la tarea de crear un pasado para alimentar con memorias lo que veían como un desierto cultural e histórico. Los textos, que en su mayor parte adoptan la forma del ensayo monumental y totalizador, apuestan a consolidar la grandeza de la nación.

El relato nacional se quiere traductor de la conexión íntima que existe entre los distintos planos de la vida comunitaria; hace visible la historia y, en este sentido, opera como mediador, rescatando valores concretos del pasado que se proyectan hacia el porvenir mientras se postula como una especie de organizador sintáctico de los fragmentos del mundo moderno imaginando una continuidad espacial y temporal donde asienta un pueblo. Ese sujeto histórico, el pueblo en el rol de pueblo patriota, contiene los sentidos del pasado y es conducido hacia la misión redentora por líderes o profetas, fuentes del discurso y, a la vez, hacedores de relatos. Al construir la memoria colectiva, los relatos funcionan como archivos que guardan las tradiciones y establecen genealogías dando testimonio de un pasado primigenio. ${ }^{2}$ Podría pensarse entonces que esas otras textualidades fragmentarias y humorísticas se dirigen contra la memoria y el archivo.

6 En 1927, Enrique Méndez Calzada escribe "El archivero enloquecido" que cuenta la historia de un hombre que, después de pasar treinta años sepultado en una pequeña sala comienza a mostrar síntomas de enajenación. El narrador diagnostica "manía encasillante o encasillomanía" (158). ${ }^{3}$ Guiado por el "delirio sistematizante", el personaje explica al narrador una curiosa teoría sobre la centralidad del archivo al punto que niega la existencia de ciencias como la historia, la geografía, la filología para poner en su lugar al archivo : al fin de cuentas, sostiene, los contenidos científicos son sólo fichas que atañen a cada dominio. Llevada a este extremo, la teoría desmiente la certeza de lo fáctico :

Los hechos, señor mío, no existen: existen las fichas que los registran en un archivo, del mismo modo que, a los cinco años de sepultado un cadáver en un cementerio, no existe tal cadáver. Lo que existe es una anotación en la oficina municipal correspondiente. Suprima usted esa anotación, y no sólo ha suprimido un cadáver sino también la posibilidad completa de demostrar que efectivamente ha ocurrido tal fallecimiento, salvo que apele a las fichas de algún otro archivo, puesto que el Registro Civil tampoco es otra cosa que un archivo, el vasto archivo biográfico de las personas sin biografías (162).

7 Los hechos como los cuerpos retroceden ante el poder de la letra mientras la inscripción adquiere estatuto de realidad. En un movimiento recursivo ad infinitum no importa cuán lejos uno vaya, siempre hay una ficha en el origen de algo, ya se trate de hechos, instituciones, ciencias, y aún de la sociedad organizada. Drástico, concluye antes de dar 
con sus huesos en el manicomio : "el archivo es la base y el fundamento de todo cuanto existe" (164). Muchos años antes de que se tornara lugar común la idea de que el discurso construye la historia, Méndez Calzada pone en marcha el postulado, mostrando que la pasión del archivo tiene sus adictos en cualquier época y en cualquier orden.

La pasión es compartida décadas después por Ricardo Piglia (1990) quien, en una entrevista de 1989, declara que en la época en que trabajaba sobre la forma de Respiración artificial pensaba en la idea de archivo ; el personaje de Osorio concebido como inversión de Sarmiento, nació de la necesidad de hallar una fuente histórica que sirviera de base para construir el archivo. ${ }^{4} \mathrm{El}$ archivo como forma literaria deseada o la literatura como archivo. El escritor en la figura de archivero plantea preguntas y busca respuestas que configuran la trama de sentidos de la historia ; la lógica implícita opera con la convicción de que la escritura puede derrotar a la muerte. Como dice Derrida (1997) escribir es un acto de memoria o archivación..$^{5} \mathrm{El}$ archivo se erige en testigo de vidas y acontecimientos. Al conservar miles de huellas diseminadas crea la ilusión de que, si desplegamos el archivo, los significados se nos harán transparentes. La ley del archivo invoca la memoria, como anámnesis, mnéme o hypómnema, sostiene Derrida que aproxima el archivo a la noción de memoria voluntaria y reproductiva mientras homologa el mal de archivo con la pulsión de muerte y ve en el deseo de archivo, la pulsión de conservación. El concepto de la literatura como archivo implica que la máquina literaria permite leer otros episodios, políticos y culturales.

9 En otra parte he analizado la obra de Arturo Cancela (Rodríguez Pérsico 2008). En esta oportunidad, me interesa otro escritor que cultiva el humor y el costumbrismo por esos años : Enrique Loncán. En Argentina, la causerie preside junto con los libros de memorias las tendencias literarias de fin de siglo XIX. Pariente del original francés de Sainte-Beuve, el género opera como cajón de sastre. Todos los temas pueden tener cabida desde que los tonos sean ligeros. La causerie huye de la gravedad y sortea cualquier profundidad siguiendo un modelo retórico que hace de la digresión un ideal estilístico. Loncán publica entre 1923 y 1936 cuatro volúmenes de causeries de título muy porteño, Las charlas de mi amigo. ${ }^{6}$ En el Prólogo a Aldea millonaria, Jean Paul, seudónimo de Juan Pablo Echagüe, juzga a las causeries como "certero estudio de psicología colectiva "hecho por "un espectador que se divierte y nos divierte" (233). En un comentario a Aldea millonaria, dice Cancela de su compañero de ruta :

Escritor actual, casi periodístico, Enrique Loncán tiene quizá mayores posibilidades históricas que los disertadores graves que trabajan pensando en las generaciones venideras. A él le ha tocado ser el pintor de un ocaso. Ha sorprendido, quizá sin proponérselo, los últimos visajes de una clase social cuyo tránsito es definitivo y que ha pasado por la historia como cruzan las aves el firmamento : sin dejar huella (506-507).

10 El autor ficticio es Américus, amigo del editor Loncán. De Américus se dice que no es escritor profesional y que se inscribe gustoso en la generación del 80. Discípulo de Wilde, Cambaceres, Mansilla y Cané, el ocio que proporciona el dinero le permite dedicarse a la escritura en un ademán que une la diversidad temática a la pose esnob. Loncán aduce motivos afectivos para editar las charlas :

Américus, el verdadero autor de estas charlas, es mi sombra. Nada ni nadie puede separarlo de mí ; me precede o me sigue incesantemente y como el reo que llega a encariñarse con su celda, no sólo estoy resignado a su compañía sino que hasta he concluido por profesarle una sincera ternura. Nada es más prudente que conformarse con el destino (105). 
11 En Mirador porteño, insiste en la fidelidad a un género, un tono y un carácter ; denomina a sus trabajos "sketchs", "causeries", "aguafuertes". La manía anacrónica de las dedicatorias lo une a Lucio V. López: "Américus es un ejemplar retardado y mediocre de aquella gran aldea que Lucio V. López exaltó en páginas memorables" (106)

Loncán se muestra un causeur agudo que actualiza el género imprimiéndole la huella política. Dicho en otras palabras, elige las formas y los tonos de la causerie decimonónica para dotarlos de contenidos políticos. La jocosidad y la burla se unen para producir un tipo de textualidad que toma distancia tanto del ademán pedagógico cuanto de la pose indignada. En "A propósito de 'Siluetas', el autor define su texto como causerie, reconociéndose un diletante del periodismo :

Así como a algunas personas se les va un ojo (sin alusión al excelentísimo señor ministro del Interior) a los dilettants del periodismo se nos suele extraviar la pluma en digresiones inútiles. Es lo que ha pasado en el curso de esta deshilvanada causerie , en cuyo principio anuncié una demostración que por fuerza debe quedar trunca aquí mismo (54)

13 Y en el amasijo de tópicos, el causeur da cabida a la nostalgia. Un pasado dorado oficia de contrapeso a la decadencia presente a través de la fisiología del guarango. Loncán -como Cancela- acude, con frecuencia, a la estrategia del extrañamiento: Américus escribe cartas a lady Chryssie Camelsfield, una amiga británica, explicando modismos, costumbres y tipos, defectos y mezquindades de la vida cotidiana criolla. En "El optimismo de los Guarangos" (Mirador porteño), el autor explica a la dama inglesa la omnipresencia del guarango en la sociedad argentina: "es como una enorme enredadera que fuese cubriendo los muros de un gran edificio, hasta disimularlo por completo" (108). Como si diseminara el virus del mal gusto, el guarango no distingue clases, ni culturas ni razas, ni siquiera espacios. Metido a sociólogo, Américus propone una serie de posibles ensayos que estudiarían el papel del guarango en la historia, el arte o la democracia, "su influencia en la evolución de nuestra sociabilidad" (108).

La distancia que va de los escritores nacionales a los humoristas porteños podría recorrerse examinando estas textualidades que aspiran a funcionar como las nuevas tecnologías y toman por modelo la fotografía y el cine (Loncán escribe Kodak porteño ; Cancela, Film porteño). Prefieren las escenas rápidas y fragmentarias, yuxtaponen esbozos de la vida cotidiana armando una sintaxis paratáctica, focalizan algunos elementos en detrimento de otros, trabajan con un recorte temporal mínimo, con el instante. En lo que podría interpretarse como afán de romper con las convenciones del relato nacional, reducen los espacios nacionales a los límites de la ciudad o incluso a ciertos barrios o determinados lugares de encuentros sociales. Los protagonistas se constituyen en el reverso de los héroes nacionales; son, en rigor, antihéroes huecos, mezquinos, prejuiciosos cuando no deshonestos y arribistas. Los textos exploran el presente sin preguntarse por el porvenir, como si la dimensión del futuro estuviera obturada.

En 1927, Kracauer (2008) señala la coincidencia temporal entre el desarrollo del pensar histórico y el de la técnica fotográfica moderna: "la fotografía ofrece un continuo espacial y el historicismo quiere completar el continuo temporal" (22) y compara las imágenes fotográficas con las imágenes de la memoria : "La fotografía capta lo dado como un continuo espacial (o temporal) y las imágenes de la memoria conservan lo dado en cuanto significa algo" (25). ${ }^{7}$ Las significaciones de las imágenes de la memoria están ligadas a la vida y la historia de un sujeto : "Los rasgos de los hombres se conservan solo en su 'historia'" (31). Y en esto se distinguen de las imágenes fotográficas. Kracauer 
reflexiona sobre una vieja fotografía de una joven que resulta luego la abuela; lo que la fotografía retiene es el continuo espacial donde estaba el sujeto cuando posó frente al objetivo, y no el sujeto en cuestión : "el ser humano no es quien aparece en su fotografía sino la suma de aquello que se puede extraer de él" (30).

La fotografía marca una interrupción temporal. Cancela escribe Film porteño, Loncán incluye en sus libros la serie "Kodak porteño; tipos que pasan...", retratos rápidos de estereotipos urbanos: "el desflorador de escándalos", "el recetador automático", "el eterno testigo presencial", "el cumplidor contagioso", "el confidente de muertos ilustres", entre otros. Las viñetas se arman sobre una escena donde se destaca el detalle que atrae la atención. Las charlas -como la fotografía- tienen la pretensión de atrapar el instante, o usando las palabras de Kracauer, de realizar la "configuración espacial de un instante". Quizás la causerie sea a la letra lo que la fotografía a la imagen.

Como forma extendida, el estilo digresivo se usa con un sentido y una orientación peculiares en la medida en que el causeur, Américus, habla de una cosa para resaltar otra : en "El amor de Juan Díaz, de Solís", una simple historia amorosa muestra el papel decisivo de la prensa en la construcción de la realidad: "Evidentemente, si la publicidad no existiera, la gloria, la riqueza, la virtud y el crimen permanecerían ignorados y por lo tanto dejarían de ser interesantes" (143). Aclaremos que los títulos aluden frecuentemente a hechos o personajes de la vida colectiva nacional. Las historias se enlazan porque gracias a la publicidad de un concurso de jabón, Carolina se casa con Juan Díaz, ganador de una casa en un barrio de Buenos Aires. A raíz de una huelga de periódicos, el país se paraliza, incluso intelectual y artísticamente : los poetas callan, los pintores abandonan los pinceles, "la elocuencia enmudeció en labios de nuestros oradores y todas las tribunas quedaron desiertas" (143). En una suerte de crescendo, la prosa hilvana ejemplos del descalabro general mediante una enumeración que acentúa el absurdo hasta culminar con la afirmación "casi nadie murió". La conclusión extrema la lógica del disparate: "Ante esa prueba irrefutable no se puede dudar de que la mayor parte de la gente nace, vive, se divierte, sufre y muere para aparecer en los diarios" (144).

Loncán practica la estrategia del sinsentido o del desvío del sentido : un título que juega con referencias a hechos históricos entra en contradicción con un contenido pedestre; toma un acontecimiento (la huelga gremial que deja al país sin medios informativos) y recorre su impacto en distintas esferas, que se yuxtaponen sin ningún orden mezclando lo importante a nivel público ("la vida parlamentaria quedó suspendida") con la nimiedad de la vida privada enunciada en clisé de columna social ("ninguna señora guardó cama"). Los términos unidos en el plano sintáctico producen disonancias semánticas. Las esferas se articulan por contigüidad y por estructura sintáctica. Por ejemplo, el narrador hace conjeturas respecto de las preferencias de los habitantes de la localidad de Solís quienes ante la pregunta sobre las cosas o monumentos que representan mejor a la comunidad, algunos asegurarían que es la prosa combativa de un periódico de la oposición, otros, el servicio fúnebre de una cochería, un cuadro teatral, un caballo ruano de alguna estancia próxima o los acrósticos de un periodista local. El texto se detiene en discutir el voto de un habitante que se inclina por Carolina Strachiari. Como una lente fotográfica, la prosa se aproxima al personaje que da título : Juan Díaz, tenedor de libros de la tienda "Blanco y Negro" y admirador de la joven de nombre sonoro. En un momento, la voz narrativa pone distancias respecto de la visión idealizada del enamorado ; hace desaparecer el encanto de la muchacha bajo la figura de un espantajo: "belleza que hubiera sido completa sin su cabellera inútil y torpemente oxigenada, sin un lunar artificial e innecesario que lucía en 
el pómulo derecho y sin el carmín excesivamente sangrientos que gritaba en sus uñas" (145). El personaje se parece al nombre. Nombre y personaje unidos en la chabacanería.

Para su propuesta de hacer la autopsia de una sociedad y de un tiempo, Loncán usa frecuentemente el procedimiento de reiterar personajes y situaciones, que revelan en clave individual, males colectivos. En varias causeries, el protagonista es un ordenanza negro -Ponciano Caseros- que trabaja en la casa de gobierno y renuncia para evitarse la afrenta de ponerle el abrigo al presidente Yrigoyen; en otras, el doctor Altamira, oscuro secretario de Juzgado que permanece en su puesto durante treinta años, encarna la existencia anodina del burócrata. Ya el título, "La caída de Caseros", alude simultáneamente a la batalla en la que es derrotado Juan Manuel de Rosas en 1852 y al protagonista que lleva el ilustre apellido. Así, la historia patria se ve desplazada por la anécdota del jefe de ordenanzas de la Cámara de Diputados. Contagiado de la retórica inflamada de los políticos de turno, el funcionario arremete contra el populismo de Yrigoyen y alaba a otros hombres públicos como Julio A. Roca, Figueroa Alcorta, Sáenz Peña o Victorino de la Plaza.

En una definición de la propia obra, comenta Américus :"¡Ah, la historia ! Sólo se ocupa de los generales, de los estadistas, de las batallas, de las revoluciones" (70). Las charlas eligen el camino opuesto en la medida en que episodios que se agotan en detalles escudriñan la realidad argentina contemporánea. Con ironía, el final recoge un panegírico conjetural del hombre que no transige ante el poder supremo. La disonancia entre la jerarquía del personaje y su discurso aparece neta; el encadenamiento de lugares comunes no se refiere a un moderno héroe de la democracia sino al oscuro funcionario que rehúsa codearse con el plebeyo Yrigoyen.

21 Pero los personajes pueden ser aún más insignificantes, lo que deriva en una mirada distanciada sobre los hechos narrados y sobre la sociedad que los protagoniza. De Aldea millonaria, título que evoca el libro de Lucio V. López, La gran aldea (1884), me detengo en "Grandeza y decadencia de una piedra pómez (Memoria autobiográfica)" (Aldea millonaria ). La narradora -una simple piedra pómez colocada en el baño presidencial de la Casa Rosada- cuenta importantes acontecimientos políticos. Sin nombrar de modo explícito a Yrigoyen, la piedra relata los cambios que se operan a partir del 16 de octubre de 1916; un par de comentarios vinculan al líder con las multitudes que lo siguen; el nuevo sujeto social adquiere los contornos amenazantes de los invasores: "Tenía el semblante espectacular y el tipo inolvidable de los dominadores de multitudes [...]" (246). La piedra cambia de dirección y de dueño. La recorrida por distintos espacios acentúa la decadencia de la piedra que pasa del boudoir de la garçonnière al baño del comité político y a raíz de una pelea entre el presidente y el secretario del partido, termina en una comisaría donde la usan para quitar de los dedos los restos de tinta.

"La conquista de Buenos Aires" se incluye en el volumen de ese nombre. El enunciado se reitera en varias charlas y remite a situaciones y sujetos que encadenan las acciones motivadas por el anhelo de conquistar la metrópoli y que desembocan en previsibles fracasos. Dedicada a Enrique Larreta, la causerie empieza al modo de una epopeya: el poeta canta a un dios para poner la composición bajo su protección. Aquí, la invocada es Agave, una de las Nereidas, a la que el protagonista-Marco Tulio Cicerón- le adjudica su resurrección; la diosa le comunica la tarea de visitar Buenos Aires a fin de mostrar su sabiduría. Desde el primer momento, Cicerón comete equívocos y se mete en apuros : en el barco, al escuchar que italianos enriquecidos hablan de liras, piensa que son poetas; desconocedor de costumbres contemporáneas, tiene un primer conflicto cuando el 
empleado de la aduana le pide el pasaporte. Después de enfrentar entuertos burocráticos en la facultad de Derecho, concurre a un almuerzo en el Rotary Club y cuando sus compañeros de mesa le preguntan por su actividad, Cicerón aclara: "Produzco elocuencia" (380). La respuesta provoca el desdén porque la elocuencia no cotiza en el mercado. Resuelto a incursionar en la política, asiste a sesiones en el Congreso donde oye discursos vacuos, "sin espontaneidad, sin calor, sin fuego" (382).

Su estupor culmina durante las exequias de Yrigoyen al comprobar que un líder sin discursos puede alcanzar la popularidad. En la lógica absurda del país, las instituciones no son espacio apropiado de la retórica. La palabra está confinada a ámbitos que no tienen relación con las instituciones republicanas. Así sucede en una escena desopilante en la que el latino siembra alusiones mitológicas e históricas mientras intenta, con escasa suerte, rematar un cerdo campeón. Ensaya luego otros oficios, cada vez más degradados, en los que intervienen la voz y la oratoria : se postula a conferencista, a profesor de griego y latín; prueba ser locutor y también valet en la puerta del teatro Colón. Desilusionado y buscando refugio en la filosofía, comprende la lección : "para el humano linaje sólo son definitivamente grandes los que ya no existen" (384). Ni Cicerón ni ningún otro personaje de Loncán -pobres marionetas presas en la frivolidad reinante- lograrán la conquista de Buenos Aires.

Pero estas figuras desastradas encuentran sus opuestos en los retratos de hombres públicos, héroes, guerreros, políticos y poetas que traza Octavio Ramón Amadeo en Vidas argentinas. Loncán comenta el libro en "La vitrina de Amadeo" (La conquista de Buenos Aires ) que el autor dedica al vicealmirante Carlos Daireaux, interventor del gobierno de Uriburu y luego Ministro de Marina : "Esta obra de Amadeo es una obra esencialmente patriótica", asegura (457). En torno de las imágenes del historiador y del crítico que investigan la verdad, la prosa pasa revista a los héroes nacionales del siglo anterior y contemporáneos -Roque Sáenz Peña, Carlos Pellegrini, Roca, Quintana- que han logrado en grados diferentes, la conquista de Buenos Aires.

La obra de Loncán perfila dos figuras complementarias : la del causeur y la del orador. El personaje de Cicerón parece ser su contrapartida ficcional, como si el escritor hubiera puesto en él la desilusión provocada por un tiempo de palabras devaluadas. En el Prólogo a He dicho, un libro de 1925 que reúne discursos de fechas diferentes, Mariano de Vedia recuerda las experiencias vividas en reuniones privadas o en asambleas públicas cuando en algún momento de la velada el público pedía :"¡Que hable Loncán !". "Se trata de un orador y de un orador elocuente", sostiene de Vedia para definir el arte de hablar como "una de las más altas, nobles y fecundas facultades humanas, vinculada al progreso de las ideas, a la difusión de los principios y las creencias, al imperio de la justicia, a las prácticas democráticas [...]" (Loncán 1925 11). En otros pasajes, subraya la autenticidad del discurso : la emoción del orador no es efecto interpretativo sino sentimiento visible: "Loncán no busca los efectos del decir. Dice bien no más, porque esa es su manera, en la que entran su naturaleza y su arte, pero él quiere, sobre todo, que sea la frase misma, abriéndose ampliamente, la que muestre en su seno, vigorosa, la idea generatriz" (12). Lejos estamos del espíritu impugnatorio y jocoso de Cancela.

Si el orador pretende convencer a un público al que desconoce, el causeur apela a la complicidad inherente al "entre nos"; no intenta persuadir porque tanto él como su auditorio comparten posiciones. El orador habla en el espacio público (en banquetes, en el teatro Colón, en la ciudad de Azul, en el cementerio, en el Teatro Olimpo de Rosario, en la imprenta de La Nación). El causeur escribe con ritmos de la oralidad y destina sus palabras 
al espacio del salón donde, en una escena imaginaria -y anacrónica- de camaradería, se reúne y departe con sus iguales. En ese espacio, hay lugar para el humor, para la mirada irónica arrojada sobre sujetos, costumbres e instituciones. El orador, por su parte, practica los tonos altisonantes del elogio personal o la alabanza de idiosincrasias colectivas : "A Francia en el peligro", de 1918, recupera para el mundo entero los ideales de derecho, justicia y libertad. "Elogio de Mitre", de 1921, traza el retrato del demócrata que debe leerse a contraluz de la figura del presidente Yrigoyen. En este discurso, Loncán construye una trilogía sagrada de la nacionalidad en torno a Moreno, San Martín y Mitre que encarnan, en su perspectiva, "el genio de la Revolución de Mayo, el numen de la Epopeya libertadora y el alma de la Unidad definitiva de la República" (77). La prosa se hace grave para describir al hombre total, al héroe que une la acción y el pensamiento en las imágenes superpuestas del soldado y del poeta mientras separa aguas distinguiendo al demócrata del demagogo en frases que condensan prejuicios y temores del presente :

Y nadie mejor que Mitre ha demostrado cómo es posible ser demócrata sin ser demagogo y cómo la democracia en el gobierno no consiste en la adulación de las bajas pasiones y de los bajos instintos de la plebe, en el cultivo oficial de sus incontinencias, de sus agravios y sus rencores, sino en la armonía y el equilibrio de todos los valores éticos y económicos que constituyen la sociedad por medio de la tolerancia y la transigencia, única ley admisible en el comercio civilizado de los hombres (80-81).

Desde 1920, Argentina vive una época de efervescencia cultural a la que contribuyen numerosos viajeros intelectuales que llegan al país para actuar en distintos ámbitos. La estada de Duchamp en Buenos Aires (entre septiembre de 1918 y junio de 1919) provee una fecha arbitraria que marca el auge de estas visitas ilustres. A partir de 1930, la figura del viajero intelectual se complementa con la del conferencista cuando, a los escenarios típicos de encuentros como los banquetes y las exposiciones, se suman las conferencias realizadas en instituciones oficiales -los diferentes recintos universitarios- o en centros alternativos, como el Colegio Libre de Estudios Superiores.

Arturo Cancela se mofa de la cultura de la conferencia y de las costumbres banqueteras en su extraordinaria novela Historia funambulesca del profesor Landormy. Mientras la inefable Norah Lange deslumbra con sus brindis festivos, mientras Macedonio Fernández hace sus piruetas verbales ancladas en la paradoja, Loncán jaquea la frívola ceremonia del banquete contando en "La sentenciosa tos del doctor Altamira" (Mirador porteño) los avatares del secretario de Juzgado que ya había aparecido en su libro anterior. Después de permanecer treinta años en su puesto, el doctor Altamira, se retira de tribunales y funda una improbable Liga Argentina contra la Cremación de Cadáveres. A partir de ese momento, frecuenta las antesalas de los ministerios, el Congreso, las redacciones de periódicos y da discursos sobre una temática poco propensa para la celebración. La tos a la que se refiere el título es la de los oradores famosos como Cicerón quien, según opina el secretario, después del acceso de tos, ganaba profundidad y fluencia.

Como en reverso del escepticismo juguetón que perfora las causeries, en los discursos, los tonos se hacen más serios a medida que avanza la década de 1930. En 1935, Loncán da a conocer Campanas de mi ciudad, campanas argentinas, libro dedicado a Monseñor Miguel de Andrea que reproduce la conferencia pronunciada el 5 de octubre de 1934, en vísperas del XXXII Congreso Eucarístico Internacional. Allí, el orador traza la historia patria a través de la historia de las campanas de iglesias, torres y edificios públicos que han actuado como testigos de los grandes acontecimientos. El orador entona acentos proféticos cuando prevé en una hipotética escena apocalíptica el rescate del pueblo argentino : 
31 Y planeando sobre las ondas de un mar azul y blanco, una gran voz dirá : esas campanas son mis campanas, las del perdón, las de la misericordia, las del amor ; allí vivió un pueblo que fue grande y fuerte porque nació por la cruz y murió con la cruz; allí alentó una sociedad que fue noble y límpida porque creyó en mí y porque de padres a hijos, a través de los siglos, se pasaron la antorcha de mi religión, de mi moral y de mi fe ; allí triunfó una patria invicta y gloriosa porque el bien fue su ideal, el trabajo su norma y la paz su esperanza; por todo ello, es mi voluntad que esas campanas suenen eternamente, ¡campanas de Buenos Aires, campanas argentinas! (Loncán 1935 100-101).

32 La imagen idealizada del pueblo educado en el bien, el trabajo y la paz dista de las masas populares yrigoyenistas. En contradicción con esa imagen, y casi en el mismo momento, la causerie "El diálogo de los bustos" (La conquista de Buenos Aires) despliega una conversación nocturna entre las estatuas de algunos presidentes argentinos que, entre otros temas, elabora varios conceptos de pueblo, sujeto de todo relato nacional : desde el enaltecimiento por Roque Sáenz Peña (recordemos que durante su mandato se sanciona el voto universal, secreto y obligatorio) hasta la imagen cristalizada del pueblo como niño grande -que debe ser guiado y custodiado- enunciada por Roca, pasando por el comentario despreciativo de Victorino de la Plaza: "el pueblo no sabe lo que quiere" (334).

El busto de Uriburu precisa la fecha histórica: se trata de 1931, momento en que se oficializa el grupo paramilitar de la Legión Cívica Argentina. La estructura dialógica enfrenta a los distintos personajes que expresan sus puntos de vista sobre cuestiones republicanas como las libertades, la democracia, los intereses grupales y nacionales considerando sus actitudes personales y sus respectivos gobiernos como punto máximo de virtudes y valores democráticos mientras el resto recorta y angosta las versiones demasiado benévolas.

Loncán y Méndez Calzada se suicidan en 1940. Después de la publicación de Historia funambulesca -la novela en episodios que condensa en clave humorística su pensamiento crítico- Cancela se llama a silencio que rompe sólo de modo muy espaciado. La historia literaria ha sido ingrata con estos escritores. Más que a elecciones político partidarias, creo que ello se debe a la apuesta que hicieron a un tipo de literatura que aniquila mitos y esencias pero no pone nada en el lugar vacío. En estas escrituras, el relato elabora instantáneas que detienen el flujo temporal. o quizás, habría que decir que el relato piensa el acontecimiento. La instantánea captura el presente visto como tiempo de decadencia. Las formas literarias del ensayo nacional y del relato costumbrista humorista escenifican modos de concebir la historia: al archivo, la memoria y la continuidad se contraponen la fragmentación, la instantánea y el presente. ${ }^{8}$

\section{BIBLIOGRAFÍA}

Barthes, Roland. Mythologies. Paris : Seuil, 1957.

Cancela, Arturo. "Helenismo en la pampa". La vida literaria, año III. № 23 (agosto de 1930). 
Derrida, Jacques. Mal de archivo. Una impresión freudiana. Madrid : Trotta, 1997

Kracauer, Siegried. "La fotografía". La fotografía y otros ensayos. El ornamento de la masa I.

Barcelona : Gedisa, Dimensión Clásica, 2008, 19-38.

Loncán, Enrique. Las charlas de mi amigo. Buenos Aires : Emecé, 1981.

Loncán, Enrique. He dicho... Brindis y discursos. Prólogo de Mariano de Vedia. Buenos Aires : M

Gleizer-Editor, 1925

Loncán, Enrique. Campanas de mi ciudad, campanas argentinas. Ilustró C. B, Rocco Perna. Buenos Aires : Viau y Zona, MCMXXXV

Méndez Calzada, Enrique. Las tentaciones de Don Antonio. Buenos Aires : Biblioteca Nacional, Ediciones Colihue, 2006.

Piglia, Ricardo. "La literatura y la vida". Crítica y ficción. Buenos Aires : Siglo Veinte, 1990.

Rodríguez Pérsico, Adriana. Relatos de época. Una cartografía de América Latina (1880-1920). Rosario : Beatriz Viterbo, 2008.

Rodríguez Pérsico, Adriana. "Arturo Cancela : una estética del desecho y la desubjetivación". Premat, Julio (ed.). Quimeras. Cuando la literatura sabe, ve, piensa. Cahiers de LI.RI.CO. Numéro 4.

Paris : Université Paris 8, 2008, p. 71-95.

Rodríguez Pérsico, Adriana. Brindis por un ocaso. De los escritores nacionales a los humoristas porteños, Buenos Aires : Santiago Arcos, 2011.

\section{NOTAS}

1. Recordemos que Gálvez escribió una Historia de arrabal y que tanto Larreta, como Rojas o Lugones inventan genealogías prestigiosas y edulcoradas que remontan a nobles antigüedades.

2. He analizado el tema en extenso en Relatos de época. Una cartografía de América Latina (1880-1920)

3. El título del libro de Méndez Calzada, Las tentaciones de Don Antonio, alude claramente a La tentación de San Antonio de Flaubert (1874).

4. "La literatura y la vida", 191.

5. Dice Derrida: "El primer archivero instituye el archivo como debe ser, es decir, no sólo exhibiendo el documento, sino estableciéndolo. Lo lee, lo interpreta, lo clasifica" (63).

6. Los cuatro libros son : Las charlas de mi amigo (Motivos porteños), 1923 ; Mirador porteño (Nuevas charlas de mi amigo), 1932 ; Aldea millonaria (Penúltima charla de mi amigo), 1933 ; La conquista de Buenos Aires (Ultima charla de mi amigo), 1936.

7. "La fotografía".

8. Posteriormente a la presentación de este artículo, una versión completada y revisada del texto fue incluida en: A. Rodríguez Pérsico, Brindis por un ocaso. De los escritores nacionales a los humoristas porteños, Buenos Aires : Santiago Arcos, 2011. 


\section{RESÚMENES}

Durante las décadas de 1920 y 1930, una serie de escritores y periodistas cultivan la crítica política en textos que fusionan costumbrismo y humor. Con algunas excepciones, prefieren las formas breves, ya sea el cuento, el aguafuerte o la causerie. Arturo Cancela, Enrique Loncán, Enrique Méndez Calzada llegan con sus escritos a un público amplio porque colaboran en periódicos y revistas de gran tirada como La Nación, El Hogar, Caras y Caretas. Profundamente escépticos, son antiyrigoyenistas y a fuerza de tanto negativismo, antidemocráticos. El blanco de sus risas es el gobierno nacional y popular. Muestran una Argentina que, entre la ruina de las instituciones, se vislumbra como una sociedad en pedazos.

Pero no sólo atentan contra los tiempos presentes. Los textos ponen en marcha una operación de desmitificación extendida de los grandes relatos nacionales. La risa y el estereotipo corroen los mitos creados por los escritores del Centenario como Leopoldo Lugones, Manuel Gálvez, Ricardo Rojas -para nombrar a los más representativos- que imaginan en sus ensayos identidades colectivas para la nación desplegando linajes reales o inventados. Los escritores nacionalistas se dan la tarea de crear un pasado para alimentar con memorias lo que veían como un desierto cultural e histórico. Los textos, que en su mayor parte adoptan la forma del ensayo monumental y totalizador, apuestan a consolidar la grandeza de la nación. Al construir la memoria colectiva, los relatos nacionales funcionan como archivos que guardan las tradiciones y establecen genealogías dando testimonio de un pasado primigenio.

Enrique Loncán publica entre 1923 y 1936 cuatro volúmenes de causeries de título muy porteño, Las charlas de mi amigo en las que actualiza el género imprimiéndole la huella política. Elige las formas y los tonos de la causerie decimonónica para dotarlos de contenidos políticos. La jocosidad y la burla se unen para producir un tipo de textualidad que toma distancia tanto del ademán pedagógico cuanto de la pose indignada. La causerie captura el presente visto como tiempo de decadencia.

Las formas literarias del ensayo nacional y del relato costumbrista humorista escenifican modos de concebir la historia : al archivo, la memoria y la continuidad se contraponen la fragmentación, la instantánea y el presente.

Pendant les années 20 et 30 , une série d'écrivains et de journalistes pratiquent une critique de nature politique dans des textes qui font fusionner costumbrismo et humour. A quelques exceptions près, ils préfèrent les formes brèves, la nouvelle, l'eau-forte ou la causerie. Arturo Cancela, Enrique Loncán, Enrique Méndez Calzada atteignent à travers leurs écrits un large public car ils collaborent à des journaux et des revues à grand tirage comme La Nación, El Hogar, Caras y Caretas. Profondément sceptiques, ils sont anti-yrigoyenistes et, à force de négativité, antidémocratiques. La cible de leurs moqueries est le gouvernement national et populaire. Ils montrent une Argentine qui, sur les ruines des institutions, apparaît comme une société réduite en morceaux. Mais ils ne font pas que s'attaquer aux temps présents. Leurs textes mettent en œuvre une opération de démystification englobant les grands récits nationaux. Le rire et les stéréotypes corrodent les mythes créés par les écrivains du Centenaire comme Leopoldo Lugones, Manuel Gálvez, Ricardo Rojas - pour ne citer que les plus représentatifs- qui imaginent dans leurs essais des identités collectives pour la nation en déployant des lignées réelles et imaginaires. Les écrivains nationalistes se donnent pour tâche de créer un passé pour fournir une mémoire à ce 
qu'ils perçoivent comme un désert culturel et historique. Les textes qui, dans leur majorité, adoptent la forme de l'essai monumental et totalisant, parient sur la consolidation de la grandeur de la nation. En construisant la mémoire collective, les récits nationaux fonctionnent comme des archives conservant les traditions et fondant des généalogies témoins d'un passé originaire.

Enrique Loncán publie entre 1923 et 1936 quatre volumes de causeries au titre typiquement portègne, Las charlas de mi amigo, où il réactive le genre en lui imprimant une marque politique. Il choisit les formes et le ton de la causerie du dix-neuvième siècle pour les doter de contenus politiques. La drôlerie et la moquerie s'unissent pour produire un type de textualité qui prend des distances tant avec le geste pédagogique qu'avec la pose de l'indignation. La causerie saisit le présent comme une époque de décadence.

Les formes littéraires de l'essai national et du récit costumbrista mettent en scène des manières de concevoir l'histoire : l'archive, la mémoire et la continuité s'opposent à la fragmentation, l'instantané et le présent.

During the 1920's and 1930's, a great number of writers and journalists produced texts of political criticism combining humour with a particular form of regionalism (costumbrismo). With some exceptions, most of them preferred brief forms : short stories, literary etchings (aguafuertes) or causeries. Because they were regular contributors to journals and magazines such as La Nación, El Hogar, Caras y Caretas, Arturo Cancela, Enrique Loncán and Enrique Méndez Calzada were able to reach large audiences. They were deeply sceptic, openly against Yrigoyen's policy and, because of their intense negativity, antidemocratic. The target of their mockery is the popular and national government. They show an Argentina that can be glimpsed as a shattered society, amidst the ruins of institutions.

But they do not confine themselves to present times. Their texts set up a strategy of extensive demystification of major national narratives. Laughter and stereotype undermine the myths created by Centenario authors, such as Leopoldo Lugones, Manuel Gálvez, Ricardo Rojas - just to name the more representative figures - all of which imagine collective identities for the nation, by displaying real or imagined lineages in their essays. Nationalist writers give themselves the duty of creating a past, in order to nourish with memories what they saw as a cultural and historic desert. The texts mainly adopt the form of monumental and totalizing essays, and attempt to consolidate the greatness of the nation. By constructing a collective memory, national narratives function as archives that hoard traditions and establish genealogies by providing testimony of a primeval past.

Between 1923 and 1936, Enrique Loncán publishes four volumes of causeries with a very porteño title, Las charlas de mi amigo, where he revisits the genre by imprinting them with a political point of view. He chooses the forms and tones of the Nineteenth-century causerie to set them with political contents. Jocularity and mockery combine to produce a certain type of textuality that outdistances the pedagogic expression as well as the contemptuous expression. The causerie captures the present as a time of decadence.

The literary forms of the national essay and of regional (costumbrista) humoristic accounts offer different ways of conceiving history: archive, memory and continuity counter with fragmentation, instantaneity and the present.

\section{ÍNDICE}

Mots-clés: Enrique Loncán, causerie, récits de la nation, critique politique, costumbrismo Palabras claves: Enrique Loncán, causerie, relatos de la nación, crítica política, costumbrismo Keywords: Enrique Loncán, causerie, national narratives, political criticism, regional literature, costumbrismo 
AUTOR

ADRIANA RODRÍGUEZ PÉRSICO

Universidad de Buenos Aires - CONICET 